\title{
A GASE OF HUGE PENILE AND SCROTAL ELEPHANTIASIS
}

\author{
Yoshihito Otsuji, Tadashi Maeda, Akira Nakashima, Yasubumi Irie, \\ Tadahiro Murayama, Kazuhide Imamura ${ }^{1}$ and Yoshio Fukuoka ${ }^{2}$
}

Received for publication 22 May 1974

\begin{abstract}
From 1955 through 1970 the transition of filarial symptomatic patients in a town of Bonotsu, located on the southernmost part of Satsuma peninsular, Kagoshima prefecture, had been investigated. The investigations showed that number of hydrocele and chyluria patients had a tendency of decrease, though new such cases occurred at times. New cases of elephantiasis were not found as far as our investigations were concerned and the number of the disease reduced by half in ten years. A case of huge elephantiasis of the scrotum and the penis we saw lately is described. The patient is a male, 44 years old, who lives in Tokunoshima, Oshima-gun, Kagoshima prefecture. The first filarial fever attack was noticed when he was 14 years old and since then the attack would usually occur after labor once or twice a month. The patient's penis had started to increase in size gradually when he was 17 years old and at 34 it grew as low as his knee joints. Afterwards the patient's penis has grown as long as his legs without being accompanied by episodes of fever attacks or chyluria. The patient's waist is $66.3 \mathrm{~cm}$ (circumference) and the largest part of the scrotum $76.8 \mathrm{~cm}$ (circumference), which shows the scrotum is larger than the patient's waist by more than $10.0 \mathrm{~cm}$. The length of the penis is $58.0 \mathrm{~cm}$; the smallest part, coronary sulcus, $43.5 \mathrm{~cm}$. A circumference of the glans penis is $50.5 \mathrm{~cm}$. Total weight of the penis and the scrotum amounts to about $18.5 \mathrm{~kg}$, which forms one-third the body weight, in contrast with the patient's height $(142.0 \mathrm{~cm})$ and body weight $(52.6 \mathrm{~kg})$. We report scrotal elephantiasis which is accompanied by penile elephantiasis, that is thought to be very rare.
\end{abstract}

\section{INTRODUCTION}

Filariasis presents such variegated symptoms as filarial fever attack, lymphadenovarix, chyluria, hydrocele and elephantiasis, etc..

Among those abnormal symptoms elephantiasis has drawn attention of the public from old times due to its unusual shape. In Japan The Kumagaishi - a historical book written about Kuma (Hitoyoshi, Kumamoto prefecture) district describes hydrocele that was seen as far back as the days of the 24th, Haruhiro (15121555), of the Sagara family and a famous painter, Hokusai Katsushika (1760-1849) painted an ukiyoe - a picture of everyday life in old Japan - of scrotal elephantiasis, which facts may indicate that in Japan filariasis has been prevalent from old times.

Typical elephantiasis cases, however, have rarely been seen recently. Table 1

Second Department of Internal Medicine, Faculty of Medicine, Kagoshima University, Kagoshima city, Japan. 1 Imamura Hospital, Kagoshima city. 2 Tokunoshima Hospital, Tokunoshima-cho, Ohshima-gun, Kagoshima prefecture. 
shows results of follow-up studies on filarial symptomatic patients made by the authors for 16 years (1954-1970) at Kiyohara which has about 1,000 population, Bonotsu-cho located on the southernmost part of Satsuma peninsular, Kagoshima prefecture. Bancroftian microfilaria positive rate among inhabitants of Kiyohara was $8.6 \%$ in 1962.

There had been eleven elephantiasis patients in 1954 and thereafter until 1965 four of them died (cause unknown) and one moved out, which made six patients were still living on investigation in 1970. Any newly occurred elephantiasis case was not found during 1954-1970. In 1954 there had been twenty-seven hydrocele patients and thereafter nine of them died and one moved out till 1965 - decrease of ten hydrocele patients - , though three new cases occurred during the period. Later in 1970 another new case of hydrocele was found.

Fourteen chyluria patients had been confirmed by the authors in 1954 and on the occasion of investigation made in 1965 it was found that three of them died, one moved out and seven new cases occurred. In addition, two new cases of chyluria were also found in 1970 .

As shown above, new chyluria cases have been found even recently, though, on the contrary, elephantiasis and hydrocele patients have become relatively rare in occurrence these days.

A case of huge penile and scrotal elephantiasis we have found lately is presented in this paper.

\section{CASE}

1) The patient (K.H.): 44 years old, male.

2) Present Address: Tokunoshima (Toku island), Ohshima-gun, Kagoshima prefecture.

3) Chief Complaints: Scrotal and penile enlargement, swelling of left lower extremity.

4) Family History: Non-contributory.

Past History: The patient has been of inborn mental deficiency to the extent that his mental power could not be expressed by the I.Q. (intelligent quotient), which forced him to give up school after first grader. A diagnosis of hypertension was made on the patient about two months ago.

Present Illness: He had lived in a hut in mountaneous terrain until thirteen years old and had never used a mosquito net notwithstanding lots of mosquitoes in and around the area. After thirteen year old he has lived in a sparsely-populated village in the level land. A filarial fever attack (high fever, ague and shiver) started to develop once or twice a month when he was fourteen years old, which continued until thirty. The fever attack usually occurred after labor such as mowing. His penis had begun to increase in size gradually at the age of seventeen and until thirtyfour it grew as low as his knee joint. At the age of thirty-four microfilariae were detected in the peripheral blood by mass blood survey performed by the health center. Diethylcarbamazine administration to him was instituted, which was suspended halfway later due to an unknown cause. Blood examination for microfilaria detection 
made on him at the age of forty showed negative. An episode of chyluria has never been seen with him so far. No any episode of a fever attack has been noted recently, either. His penis at present has grown as long as his lower extremity. The patient has never complained of dysuria except 'oozing out of urine from the tip of the penis' when he feels urination terminates.

System Review: Physique moderately developed. Nourishment fair. Countenance is idiotic with a relatively smaller head in size. Puls rate is 74 per minute with regular rythm and good tension. Blood pressure $152 / 70 \mathrm{mmHg}$. Neither anaemia nor icterus are noted. Physical findings of the lungs, the cardiac and the abdomen are not remarkable. There is no significant lymphadenopathy in the cervical and the axillary regions. A soybean-sized lymph node is palpable in the both inguinal regions. There is overall enlargement of the left lower extremity but neither redness nor keratosis of the skin are noted. The huge penis and scrotum are seen.

Findings of the scrotum and the penis (Fig. 1 and photographs):

Measurements are as follows: Total weight of both the penis and the scrotum

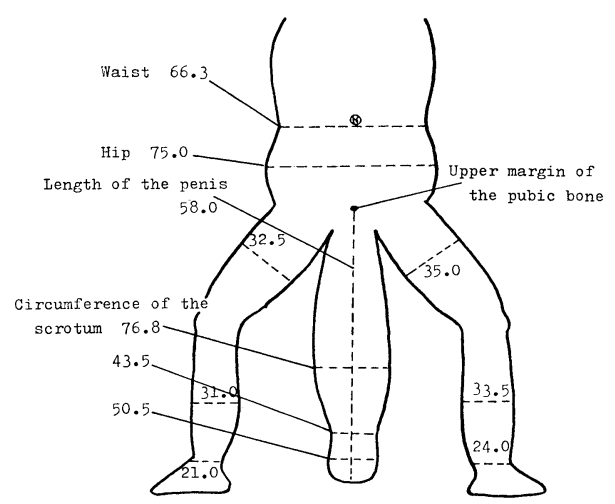

Fig. 1 Measurements (cm).

Body length $142.0 \mathrm{~cm}$; Body weight $52.6 \mathrm{~kg}$; Penis + Scrotum $18.5 \mathrm{~kg}$

TABLE 1 Transition of symptomatic patients at Kiyohara

\begin{tabular}{|c|c|c|c|c|c|c|c|}
\hline \multirow[b]{2}{*}{ Diseases } & \multirow{2}{*}{1954} & \multicolumn{4}{|c|}{$\begin{array}{l}\text { Transition of No. of symptomatic pa- } \\
\text { tients in } 11 \text { years }\end{array}$} & \multirow{2}{*}{$\begin{array}{l}\text { as of } \\
1965\end{array}$} & \multirow{2}{*}{$\begin{array}{l}\text { newly-occurred } \\
\text { cases in } 1970\end{array}$} \\
\hline & & $\begin{array}{c}\text { died } \\
\text { patients }\end{array}$ & $\begin{array}{l}\text { moved out } \\
\text { patients }\end{array}$ & total & $\begin{array}{l}\text { newly-occurred } \\
\text { patients }\end{array}$ & & \\
\hline Elephantiasis & 11 & 4 & 1 & 5 & 0 & 6 & 0 \\
\hline Hydrocele & 27 & 9 & 1 & 10 & 3 & 20 & 1 \\
\hline Chyluria & 14 & 3 & 1 & 4 & 7 & 17 & 2 \\
\hline Total & 52 & 16 & 3 & 19 & 10 & 43 & 3 \\
\hline
\end{tabular}


amounts to about $18.5 \mathrm{~kg}$, which forms one-third the body weight, in contrast with his height $(142.0 \mathrm{~cm})$ and body weight $(52.6 \mathrm{~kg})$. The length of the penis is $58.0 \mathrm{~cm}$. The largest part of the scrotum measures $76.8 \mathrm{~cm}$ in circumference which is larger than the waist $(66.3 \mathrm{~cm})$ by more than $10.0 \mathrm{~cm}$. The smallest part of the penis, coronary sulcus, is $43.5 \mathrm{~cm}$ and glans penis $50.5 \mathrm{~cm}$. A 'cleft' is visualized on the tip of the penis, out of which urine is seen oozed, though an external meatus urinarius cannot be confirmed. The surface of the penis is rigid and uneven with abundant warty and nodular protuberances and furrows on it. Scattered brown or black pigmentary deposits are seen as well. Elephantiasis of the left lower extremity is present, but keratosis of its skin is not so remarkable.

Laboratory Data (Table 2): The main laboratory data are as follows:

TABLE 2 Results of laboratory examination

\begin{tabular}{|c|c|c|c|c|c|}
\hline 1. & \multicolumn{2}{|l|}{ Microfilaria negative } & \multicolumn{2}{|l|}{ Albumin } & 48 \\
\hline 2. & \multicolumn{2}{|c|}{ FPT Intradermal reaction positive } & \multicolumn{2}{|l|}{$\mathrm{BUN}$} & $20 \mathrm{mg} / \mathrm{d} l$ \\
\hline 3. & \multicolumn{2}{|c|}{ VBS Intradermal reaction negative } & \multicolumn{2}{|l|}{ Uric acid } & $7.0 \mathrm{mg} / \mathrm{d} l$ \\
\hline \multirow[t]{4}{*}{4.} & \multicolumn{2}{|l|}{ Blood examination } & \multicolumn{2}{|l|}{ Creatinine } & $0.7 \mathrm{mg} / \mathrm{d} l$ \\
\hline & $13.4 \xi$ & $13.4 \mathrm{~g} / \mathrm{d} l$ & \multicolumn{2}{|l|}{$\mathrm{Na}$} & $132.7 \mathrm{mEq} / l$ \\
\hline & RBC $389 \times$ & $389 \times 10^{4}$ & \multicolumn{2}{|l|}{$\mathrm{K}$} & $4.7 \mathrm{mEq} / \mathrm{l}$ \\
\hline & WBC $\quad 8,250$ & 8,250 & \multicolumn{2}{|l|}{$\mathrm{Cl}$} & $105.0 \mathrm{mEq} / l$ \\
\hline \multicolumn{3}{|c|}{ 5. Blood picture } & \multicolumn{2}{|l|}{$\mathrm{Ca}$} & $4.15 \mathrm{mEq} / l$ \\
\hline & Stab & $3 \%$ & \multicolumn{2}{|l|}{$\mathrm{P}$} & $4.4 \mathrm{mg} / \mathrm{d} l$ \\
\hline & Seg I 6 & 6 & \multicolumn{2}{|l|}{$\mathrm{Fe}$} & $120.0 \mathrm{mcg} / \mathrm{d} l$ \\
\hline & Seg II 18 & 18 & \multicolumn{2}{|c|}{ Icterus index } & 4 \\
\hline & Seg III 20 & 20 & \multicolumn{2}{|l|}{ SGOT } & 18 \\
\hline & Eosino 5 & 5 & \multicolumn{2}{|l|}{ SGPT } & 9 \\
\hline & Baso & 1 & \multicolumn{2}{|l|}{ TTT } & 2.9 \\
\hline & Lymph 44 & & ZTT & & 11.0 \\
\hline & Mono 3 & & Cholesterol & & $170 \mathrm{mg} / \mathrm{d} l$ \\
\hline & BSR & & Ester ratio & & $78.7 \%$ \\
\hline & $30 \mathrm{~min} .10 \mathrm{~m}$ & & Lipoprotein & & $388 \mathrm{mg} / \mathrm{d} l$ \\
\hline & $60 \mathrm{~min} .27 \mathrm{~m}$ & & Neutral fat & & $125 \mathrm{mg} / \mathrm{d} l$ \\
\hline & $120 \mathrm{~min} .58 \mathrm{~m}$ & & Phospholipi & & $140 \mathrm{mg} / \mathrm{d} l$ \\
\hline 7. & Urinalysis & & NEFA & & $0.41 \mathrm{mg} / \mathrm{d} l$ \\
\hline & $\mathrm{pH} \quad 6.0$ & & Alkaline $\mathrm{Ph}$ & sphate & $6.0 \mathrm{u}$ \\
\hline & Protein $(+)$ & & Choline est & rase & 0.68 \\
\hline & Sugar $(-)$ & & Amylase & & $170 \mathrm{u}$ \\
\hline & Urobilinogen & & LAP & & $85 \mathrm{u}$ \\
\hline & Keton body & & Au Antigen & $(-)$ & \\
\hline & Occult blood & & CRP & $(+)$ & \\
\hline 8. & Blood biochemistry & & RA & $(-)$ & \\
\hline & Serum protein & $7.6 \mathrm{~g} / \mathrm{d} l$ & ASLO & $50 \times$ & \\
\hline & $\mathrm{A} / \mathrm{G}$ & 0.92 & LE cell & $(-)$ & \\
\hline & $\alpha 1$ Globulin & $4 \%$ & $\operatorname{IgA}$ & & $240 \mathrm{mg} / \mathrm{d} l$ \\
\hline & $\alpha 2$ Globulin & 9 & $\operatorname{IgM}$ & & $90 \mathrm{mg} / \mathrm{d} l$ \\
\hline & $\beta$ Globulin & 14 & IgG & & $1,800 \mathrm{mg} / \mathrm{d} l$ \\
\hline & $\gamma$ Globulin & 25 & & & \\
\hline
\end{tabular}


Microfilariae in the peripheral blood negative. FPT reaction (filarial intradermal reaction) positive. VBS reaction (intradermal reaction for paragonimiasis) negative. Slight anemia is present and eosinophilia is not so clear. Erythrocyte sedimentation rate is $27 \mathrm{~mm}$ in one hour (Westergren), which is slightly accelerated. Hypergammagloburinemia is present as well as slightly high level of serum Ig-G and slightly low level of cholin-estelase. Proteinuria and urinary occult blood are moderately positive.

\section{Discussion}

Kagoshima prefecture is on the southernmost part of the Japanese mainland with a favorable mild climate and much rain. Tokunoshima is, in particular, a small island which has an area of about 250 square kilometers located to the south of Amami-honto (main Amami island) which is about 500 kilometers from the Kagoshima mainland. The annual mean temperature there is $21 \mathrm{C}$ and it is over $20 \mathrm{C}$ for eight months from April through November, which is thought to agree with the growth of filarial larvae and mosquitoes.

The result of filarial investigations made in Tokunoshima from prewar period until 1960 is shown in Table 3 which reveals 153 microfilaria positive persons were

TABLE 3 Results of filarial investigations in Tokunoshima

\begin{tabular}{|c|c|c|c|c|c|c|}
\hline \multirow{7}{*}{ 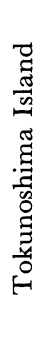 } & Localities & $\begin{array}{l}\text { No. of persons } \\
\text { examined }\end{array}$ & Mf. positives & $\begin{array}{c}\text { Mf. positive rate } \\
(\%)\end{array}$ & Reported by & year \\
\hline & \multirow{4}{*}{ 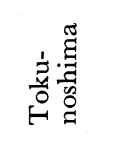 } & 118 & 47 & 39.8 & Yoshinaga et al. & 1913 \\
\hline & & 216 & 16 & 7.4 & Sameshima et al. & 1954 \\
\hline & & 251 & 37 & 14.7 & Sato et al. & 1955 \\
\hline & & 392 & 43 & 11.0 & Fukushima et al. & 1960 \\
\hline & \multirow{3}{*}{ 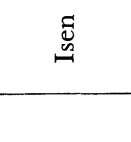 } & 27 & 4 & 14.8 & Sato et al. & 1956 \\
\hline & & 41 & 6 & 14.6 & Sato et al. & 1956 \\
\hline & & 1,045 & 153 & $14.6(\%)$ & & \\
\hline
\end{tabular}

found among 1,045 examined (microfilaria positive rate $14.6 \%$ ). For eight years from 1962 an anti-filaria policy sponsored jointly by central government and Kagoshima prefecture was taken and great results were realized consequently. The result of a government-sponsored anti-filaria work performed in 1962 by Kagoshima prefecture shows 8,968 microfilaria positive persons were detected out of 135,557 examined (microfilaria positive rate $6.6 \%$ ). As far as the inhabitants of Tokunoshima were concerned 1,254 microfilaria carriers were detected among 10,642 persons examined as shown in Table 4, which reveals considerably higher microfilaria positive rate of $11.8 \%$. All microfilariae were Wuchereria bancrofti species. As described above, Tokunoshima has been heavily infested with filarial worms since prewar period and all the worms detected there belonged to Bancroftian species. In connection with 
TABLE 4 Results of filarial investigations (Kagoshima prefecture, 1962)

\begin{tabular}{c|ccc}
\hline Localities & No. of persons examined & Mf. positives & $\begin{array}{c}\text { Mf. positive rate } \\
(\%)\end{array}$ \\
\hline Tokunoshima & 4,454 & 662 & 14.9 \\
\hline Amagi & 3,133 & 246 & 7.9 \\
\hline Isen & 3,055 & 346 & 11.3 \\
\hline & 10,642 & 1,254 & $11.8(\%)$ \\
\hline
\end{tabular}

the filarial symptomatic patients in Tokunoshima Sameshima et al. (1954) reported that they had found eighty patients including twelve hydrocele and twelve elephantiasis ones respectively. However, thanks possibly to filarial mass treatment carried out since 1962 microfilaria positive rate has decreased lately and in 1969 it decreased as low as $0.8 \%$ (40 microfilaria positives out of 4,610 examined) in Tokunoshima. With the decrease of microfilaria positive rate number of filarial symptomatic patients has also fallen off remarkably.

According to reports in the past, Blanchard (1900) reported a case of 224 pound scrotal elephantiasis and Pelletier (1912) a $100 \mathrm{~kg}$ one. The largest scrotal elephantiasis case ever reported in Japan is one found by Akaboshi, which weighed $63 \mathrm{~kg}$ and was $185 \mathrm{~cm}$ in transverse and $183 \mathrm{~cm}$ in longitudinal circumference. The case of elephantiasis presented in this paper is rather smaller in size when compared with those 'giant' scrotal elephantiasis cases reported in the past. However, in addition to scrotal elephantiasis, the case is accompanied by penile elephantiasis, which is thought to be very rare. The patient has been of mental weakness that it was very difficult to take medical history directly from him and we were obliged to depend on his families and neighbors for the most medical informations on the patient.

A case of huge penile and scrotal elephantiasis accompanied by that of the left lower extremity is presented in this paper.

\section{REFERENCES}

1) Ando, M. (1971): Studies on Epidemiology and Mass-treatment of Filariasis, Medical J. Kagoshima Univ., 23 (2), 545-580

2) Ibusuki, E. (1956): A Study on Filariasis, Report II; A Study on Filariasis in the Island of Amami-oshima (Part II), Medical J. Kagoshima Univ., 8 (1), 99-107

3) Otsuji, Y. (1955): A Study on Filariasis, Report II; A Study on Wuchereriasis in the Village of Bo-no-tsu, Kagoshima Prefecture, Medical J. Kagoshima Univ., 7 (2), 283-289

4) Sameshima, S., Tsuzaki, H., Ikebukuro, H., Kakinoki, N. and Tashiro, G. (1955): A Study on Filariasis in Southern Amami-oshima, Medical J. Kagoshima Univ., 7 (2), 239-245

5) Yokogawa, S. and Morishita, K. (1931): Handbook of Human Parasitology II, 260-263, The Tohodo-Shoten, Tokyo. 
巨大な陰茎，陰囊象皮病の 1 例

尾辻義人 ${ }^{1} \cdot$ 前田 忠 $^{1} \cdot$ 中島 $^{\text {晢 }}{ }^{1} \cdot$ 入江康文 $^{1}$

村山忠裕 $^{1} \cdot$ 今村一英 ${ }^{2} \cdot$ 福岡義雄 ${ }^{3}$

フィラリア症は，フィラリア性熱発作，リンパ管炎，乳び尿，陰孁水腫，象皮病等の多彩を症状を呈 する疾患である。鹿児島県はバンクロフト糸状虫症の濃厚な流行地であり, 特に奄美大島地区は高度な 浸淫がみられ，1962年のフィラリア検診の結果でも Mf 陽性率は11.8\%で，かつては多くの典型的な象 皮病患者がかなりみられた。然しながら最近では典型的な象皮病をみる機会は減少しつつあり，著者 が行った鹿児島坊津町清原地区における，1954年から1965年にいたる11年間のフィラリア有症者の追跡 調查の結果をみると, 陰囊水腫 3 例, 乳び尿 7 例の新発生をみているが, 象皮病の新発生は 1 例もなか った。すなわち乳び尿等は新発生があるが象皮病患者は半減していた。最近我々は，巨大な陰茎，陰囊 象皮病患者を経験したので報告する。症例は鹿児島県大島郡徳之島在住の44才の男性である。生来の白 疾で IQ は測定不能であった。生後13才迄は蚊の多い山間の家に住んでいた。14才の頃から月に $1 \sim 2$ 回熱発作があり，30才位迄続いた。17才頃から陰茎が異常に大きくなりだして34才の時には膝位の長さ になった。34才の時保健所の検診でミクロフィラリア陽性といわれ治療を受けた事がある。当科初診時, 陰茎長は恥骨上縁加ら $58 \mathrm{~cm}$, 陰囊周は $76.8 \mathrm{~cm}$, 冠状溝周 $43.5 \mathrm{~cm}$, 亀願周 $50.5 \mathrm{~cm}$ であった。陰囊, 陰茎を合わせた重量は $18.5 \mathrm{~kg}$ （患者体重 $52.6 \mathrm{~kg}$ ）もあった。外尿道口は判然としなかったが，亀頭 先端に不規則にみられる溝から尿が滲みだしていた。各種の検查を行ったが $\mathrm{EPT}$ 皮内反応が陽性であ り\%赤沈值中等度促進, 軽度の貧血, 尿蛋白 $(+), \mathrm{CRP}(+)$ の他には特に異常所見はみられなかった。 

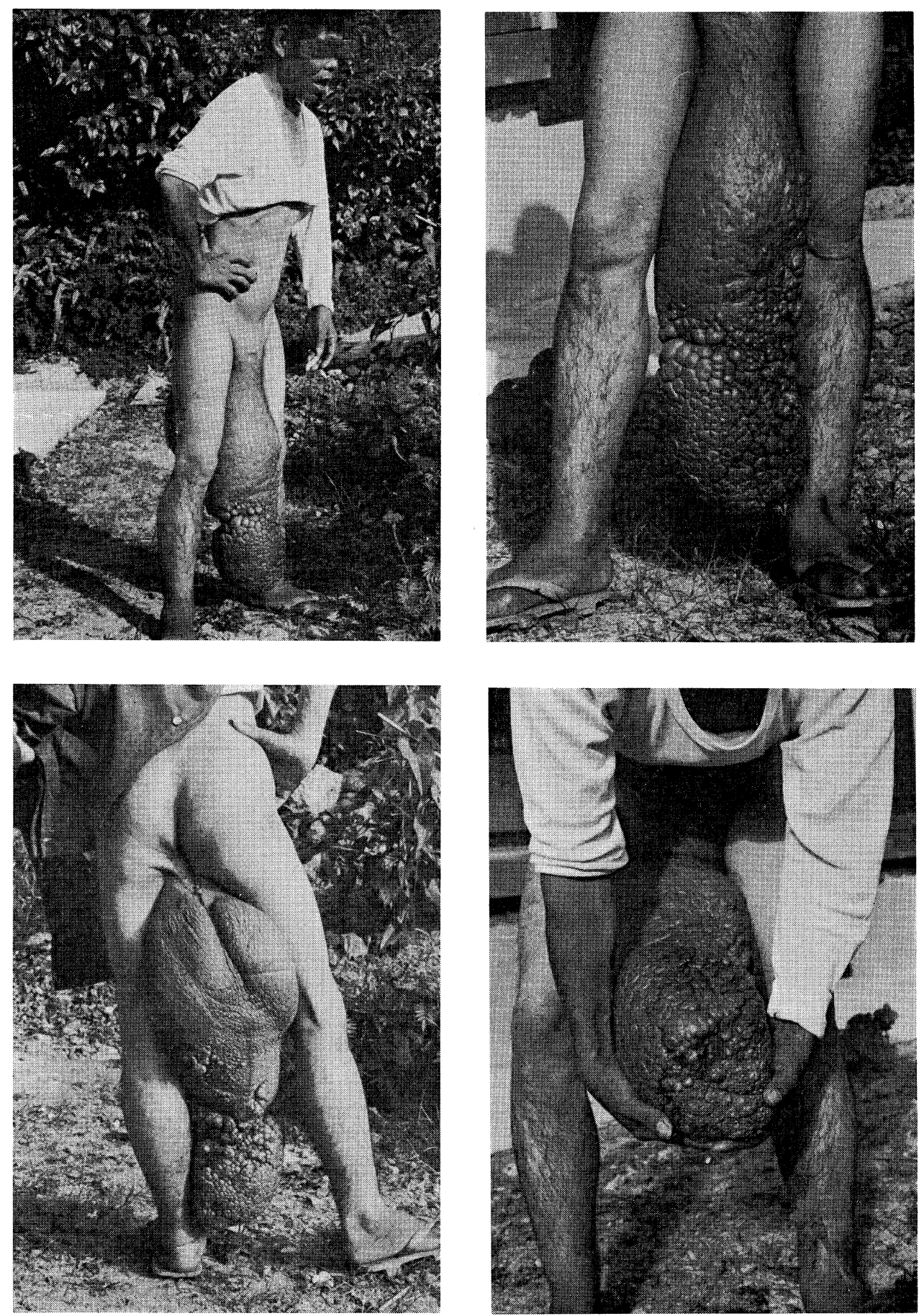